\title{
LENKIJOS, RUSIJOS IR ČEKIJOS ARCHYVŲ ŠALTINIAI APIE LIETUVOS KARINES PAJËGAS
}

\section{Prof. hab. dr. Valdemaras Rezmeris (Waldemar Rezmer)}

Daugiau kaip prieš 80 metų Lietuva tapo nepriklausoma valstybe. Pradėję formuotis tautinès kariuomenés junginiai greitai peraugo ị reguliariają Lietuvos kariuomenę, egzistavusią iki 1940 m.

Lenkijos ir užsienio šalių karo istorijos literatūroje nėra veikalo, kuriame būtų nagrinejjama Lietuvos kariuomenès istorija 1918-1940 m. Tarpukario metais pradètus šio laikotarpio tyrinejjimus nutrauke Antrasis pasaulinis karas. Po karo moksliniai periodiniai leidiniai kartais išspausdindavo darbų apie prieškarinès Lietuvos kariuomenę. Dẻl politinių priežasčių, dèl "vadovavimo" mokslui (ypač akivaizdaus karo istorijos tyrinejjimuose) Lietuvos tautine kariuomenè sovietinejje Lietuvoje (ir visoje SSRS) bei Rytų bloko šalyse buvo pasmerkta užmarščiai. Sovietiniai istorikai šią tematiką dažniausiai nutylėdavo, o jeigu ir prabildavo apie tautinę Lietuvos kariuomenę, stengdavosi parodyti ją kuo blogiau. Anot jų, ši kariuomenẻ buvusi buržuazinè, reakcinès ir fašistinès valdžios atrama - įrankis, naudotas kovai prieš darbininkų komunistini judejjimą ir kitas neva pažangias visuomenines politines jẻgas.

Per pastaruosius penkiasdešimt metų daugiausia darbų apie prieškarinę Lietuvos kariuomenę pasirodė Vakarų šalyse. Juos rašydavo lietuvių emigrantai, dažniausiai buvę karininkai. Tačiau jų darbuose buvo nemaža klaidų, nes jie remdavosi sąlygiškai negausiais šaltiniais. Paprastai jie naudodavosi prieškaryje spausdintais dokumentu rinkiniais, pasakojimais ir prisiminimais bei Vakaruose esančia šios srities literatūra: jiems buvo neprieinami SSRS ir kitų Rytų bloko šalių mokslo įstaigų archyvai.

Lietuvai atgavus nepriklausomybę, situacija pasikeitè. Nuo dešimtojo dešimtmečio pradžios lietuvių istorikai èmé skirti daug daugiau démesio tarpukario kariuomenei, išleistos kelios knygos ir išspausdinta keliasdešimt straipsnių. Tačiau kai kuriuose darbuose taip pat kartojosi daug klaidingų tezių, nors Lietuvos kariuomenès formavimosi aplinkybès, organizacinès struktūros permainos 1918-1940 m., karininkų ir puskarininkių personalo, kariuomenès dydžio, apginklavimo bei aprūpinimo problemos buvo nušviestos naujai. Neanalizuojant visų šių darbų mokslinès 146 
vertès, reikia pabrèžti, kad Lenkijoje jie paskatino tirti ne tik Lietuvos kariuomenès istoriją ir lietuvių pastangas sukurti suverenią valstybę, bet ir 1919-1920 m. lenkų-lietuvių ginkluotą konfliktą bei Lenkijos ir Lietuvos karinius santykius nuo 1921 iki 1939 m. Šie klausimai yra labai susiję.

Lenkijoje didžioji dalis dokumentų, susijusių su Lietuvos kariuomenès istorija, yra Centriniame karo archyve Varšuvoje. Šios problemos tyrinėtojus ypač turètų sudominti dokumentų rinkinių komplektas "Vidurio Lietuvos kariuomenès vadovybė”. Ši komplektą sudaro septyni rinkiniai: Vidurio Lietuvos kariuomenès vadovybè, Krašto apsaugos štabas, Krašto apsaugos departamentas, "Benekonių" grupès vadovybė, Vidurio Lietuvos kariuomenès I korpusas, Karinès apygardos "Vilnius" vadovybè, 1 rezervinè brigada. Iš viso Centrinis karo archyvas Varšuvoje turi 212 archyvinių vienetų, kurių dokumentai tiesiogiai susiję su Vidurio Lietuvos karinėmis pajėgomis. Pirmajame iš minètų rinkinių - Vidurio Lietuvos kariuomenès vadovybe - ypač įdomi II skyriaus medžiaga: žvalgybos skyriaus pranešimai bei ménesinès ataskaitos, perimti lietuvių ịsakymai, belaisvių parodymai bei belaisvių tardymo protokolai, Baltarusijos reikalų sektoriaus savaitiniai raportai, Gynybos skyriaus ataskaitos bei kasdieniai ir dvisavaitiniai pranešimai, II skyriaus atstovybès Vilniuje informaciniai (savaitiniai) pranešimai. Tame pačiame rinkinyje taip pat yra III skyriaus dokumentai (pvz., 2 armijos, 1 lietuvių-baltarusių divizijos, 1 lietuvių-baltarusių brigados operatyviniai įsakymai, Vidurio Lietuvos kariuomenès dislokacijos brèžiniai, organizaciniai potvarkiai, Mokymo programos, vardiniai demobilizuotų karių sąrašai, inspekcijų ataskaitos) bei IV skyriaus dokumentai (pvz., organizaciniai įsakymai ir potvarkiai, Saugumo tarnybos raportai apie situaciją, kasdieniai pranešimai apie materialinę situaciją).

Labai gausių žinių apie Lietuvos kariuomenę esama Lenkijos kariuomenès Generalinio štabo II skyriaus bei Karo ministerijos II skyriaus dokumentuose. 1919-1921 m. žvalgybos ir analitiniai poskyriai šias žinias surinko ir apdorojo. Tai įvairiausi pranešimai, periodiniai informaciniai raportai apie Lietuvos karinę-politinę situaciją, detalūs operatyviniai pranešimai apie Lietuvos kariuomenès išsidėstymą karo veiksmų metu (Ordre de Bataille), Lietuvos kariuomenès dislokacijos bréžiniai (piešti aliejiniais dažais) bei žemèlapiai, raportai apie lietuvių puolamuosius veiksmus lenkų-lietuvių fronte (1920 m. liepos-spalio mèn.), lenkų karininkų, dalyvavusių šiuose mūšiuose, parodymai ir pranešimai. 
Lenkijos operaciniu junginių ir net divizijų, kovojusių fronte prieš lietuvius, dokumentai bus labai naudingi atskleidžiant Lietuvos kariuomenès būklę ir išaiškinant atskirų mūšių eigą. Pvz., iš kai kurių 2-osios armijos dokumentų matyti Lietuvos kariné situacija $1921 \mathrm{~m}$. sausio ir birželio mėnesiais. Panašių archyvinių pranešimų esama ir Lenkijos kariuomenès vadovybės III ir IV skyrių dokumentų rinkiniuose. Tarp Savanorių divizijos kanceliarijos dokumentų aptinkame 19201004 pranešimą apie numuštą ties Varèna lietuvių léktuvą (tai buvo lèktuvas $L V G C V I$, jo igula - Juozas Kumpis ir Juozas Pranckevičius).

Tyrinètojų dėmesio nusipelno ir kiti dokumentų rinkiniai. Pvz., Lenkijos kariuomenès Generalinio štabo II skyriaus I atstovybejje yra keletas archyvinių vienetų, kurių dokumentai susiję su Lietuvos kariuomene trečiajame dešimtmetyje. Generalinès karinių pajègų inspektūros dokumentų rinkinyje aptinkame operatyvinius tyrimus, pvz., gen. Leono Berbeckio karo veiksmų prieš Vokietiją ir Lietuvą planus, parengtus $1927 \mathrm{~m}$.

Lietuvos kariuomenès dokumentu yra ir Rusijos archyvuose. Rusijos Federacijos valstybiniame archyve ( Государственный Архив Российской Федерации - ГАРФ) aptiktas vienas ypač i̇domus dokumentas, tai 1921 m. parengtas Lietuvos kariuomenès aprašas rusų kalba (5866 fondas, 1 aprašas, 126 byla).

Dar turtingesnių šaltinių, susijusiu su Lietuvos kariuomene, yra kitame Maskvos archyve - Istorinių ir dokumentinių kolekcijų saugojimo centre (Центр Хранения Историко-Документальных Коллекций - ЦХИДК; buvęs Центральный Государственный Особый Архив CССР ir Особый Архив Главархива СССР). Reikia pažymėti, kad šiame archyve yra sukaupti dokumentai, kuriuos 1939-1945 m. Raudonoji armija pagrobe Rytu ir Vidurio Europoje. Lenkijos Vyriausiojo štabo II skyriaus dokumentai sudaro labai didelę šio archyvo aktų rinkinio dali. Daugiausia dokumentu, susijusių su Lietuvos kariuomene, yra 308 fonde. Jame yra Lenkijos kariuomenès Generalinio (Vyriausiojo) štabo informacija apie Lietuvos politinę situaciją ir jos karines pajëgas 1919-1938 m. Šiuose dokumentuose galima aptikti ịvairių Lietuvos kariuomenès dalinių dezertyrų parodymus, Lenkijos karo atašè Paryžiuje, Latvijoje, Estijoje ir Švedijoje raportus ir pranešimus apie Lietuvos perkamus ginklus ir amuniciją, pranešimus apie Lietuvos vyriausiosios karo vadovybės reorganizaciją bei apie atskirų ginklų rūšių ir dalinių permainas, apie asmenų pasikeitimus kariuomenèje, vyriausiųjų Lietuvos karo vadų charakteristi- 
kas (pvz., gen. Stasio Raštikio, gen. Juliaus Čapliko, plk. Kazio Griniaus, plk. Stasio Dirmanto), pastabas apie vidaus politinę situaciją ir nuotaikas Lietuvos kariuomenèje, pranešimus apie diversijas ir ginkluotus susirẻmimus Lenkijos-Lietuvos pasienyje trečiajame dešimtmetyje. Panašios medžiagos yra ir kituose fonduose (pvz., 307, 471).

Rusijos valstybiniame karo archyve Maskvoje (Российский Государственный Военный Архив - РГВА, buvęs Центральный Государственный Архив Советской Армии - Centrinis valstybinis Raudonosios armijos archyvas) yra labai svarbių Pabaltijo karinės apygardos (Specialiosios Pabaltijo karinès apygardos) RKKA 1940-1941 m. dokumentų (37848 fondas, 1 aprašas, 1-45 bylos) bei 29 Šaulių korpuso dokumentu (36396 fondas, 1 aprašas, 1 byla). Tarp jų yra dokumentų, galinčiu atskleisti Lietuvos liaudies armijos dislokaciją 1940 m. vasarą, SSRS Gynybos komisariato potvarkių Pabaltijo karinės apygardos Karo tarybai, Specialiosios Pabaltijo karinès apygardos Karo tarybos nutarimu dèl Estijos, Latvijos ir Lietuvos liaudies armiju performavimo ì 22, 24 ir 29 šauliu korpusus, Specialiosios Pabaltijo karinès apygardos Stabo įsakymų ir potvarkių 22, 24, 29 šaulių korpusų vadams.

Istorikams, tyrinejantiems tarpukario Lietuvos politines ir karines problemas, labai svarbūs gali būti Cekijos archyvụ dokumentai iš Karo istorijos archyvo (Vojenskż Historickż Archiv - VHA) ir Centrinio valstybės archyvo (Sttni Śstedni Archiv - SA) Prahoje.

VHA įdomiausi yra du dokumentu komplektai: Krašto apsaugos ministerija - Prezidiumas (Ministerstwo Narodni Obrony - Prezidium) bei Respublikos Prezidento karo kanceliarija (Vojenska Kancelr Presidenta Republiky). Pirmajame yra, pvz., dokumentų, susijusių su Klaipėdos krašto prijungimu prie Lietuvos 1923 m., Čekoslovakijos konsulato Kaune pranešimai ir ataskaitos apie Lietuvos kariuomenès reorganizacijos planus (1923 m.), apie 1 Lietuvos didžiojo kunigaikščio Gedimino I pėstininkų pulko būklę, informacija apie Lietuvos vyriausiojo intendanto Vlado Grudzinsko prièmimą ị Prahos Intendantūros mokyklą, Užsienio reikalų ministerijos pranešimai, kad ukrainiečiai neprièmami ị Lietuvos kariuomenę, Čekoslovakijos karo atašè Varšuvoje pranešimai apie Lenkijos ir Lietuvos konfliktą (1923 m.) ir t. t. Panašios medžiagos yra ir kitame dokumentų komplekte. Čia yra Čekoslovakijos konsulo Galio (Galli) informacija apie plk. Vlado Skorupskio paskyrimą I pėstininkų pulko vadu, 1924 m. Krašto apsaugos ministerijos Prezidiu- 
mo parengtos žinios apie naujaji Lietuvos krašto apsaugos ministrą Teodorą Daukantą, čekų konsulato Kaune pranešimai apie Lietuvos kariuomenès biudžetą ir organizaciją 1924 m., Užsienio reikalų ministerijos pranešimai apie 2-osios péstininkų divizijos vado majoro Balio Giedraičio paskyrimą Lietuvos karo atašè Prahoje, Čekoslovakijos karo atašè Varšuvoje informacija apie Lenkijos ir Lietuvos konfliktą ir jo išsprendimą (1938 m.), Čekoslovakijos konsulo Kaune Lietuvoje surengtų iškilmių, minint Čekoslovakijos kariuomenès dešimtmetị ataskaita, Čekoslovakijos diplomatinès atstovybès Kaune periodinès situacijos Lietuvoje ataskaitos (1938 m.).

Prahos SUA taip pat galima rasti daug įdomių dokumentų. Dokumentu komplekte “Zbrojowka v Brné 1924-1942” esama medžiagos apie šios firmos, kuri buvo didžiausia prieškarinèje Čekoslovakijoje ir viena iš didžiausių tarpukario Europoje, veiklą. Čekoslovakijos ginklų gamyklos buvo svarbiausios tiekejjos aprūpinant Lietuvos kariuomenę ginklais ir amunicija. Šiame archyve taip pat saugomi dokumentai apie Cekoslovakijos ginklų pramonę ir ǐvairiausių karo reikmenų gamybą. Verta paminèti ir kitus rinkinius: “Československé konzulty v zahranii 1924-1938”, "Konsulty v ČSR 1924-1938", "Polska a Litva 1920-1940 i 1938-1944", “Baltsk stty a SR 1924-1940”. Šie dokumentai pateikia puikiausios medžiagos apie tarpukario Vidurio Europos šalių tarpusavio politinius ir karinius santykius. Dokumentai, kuriuose nušviečiami Lietuvos santykiai su Čekoslovakija ir Vokietija, gali sudominti diplomatijos istorikus. Šie dokumentai saugomi rinkiniuose: “ČSR a Litva 1923-1939" ir "Litva a ČSR 1923-1939”, “Litva a Nmecko 1923-1943 i 1935-1944”, “Nmecko a Litva 1923-1943 i 1935-1944”, “Nmecko a Memel 1922-1939”. Dokumentai apie Lietuvos politinę, ūkinę, socialinę, karinę ir t. t. situaciją sutelkti rinkinyje "Litva 1922-1944 i 1935-1945 oraz 1939-1944".

Straipsnyje pateikiau tik svarbiausius dokumentų rinkinius, saugomus Lenkijos, Rusijos ir Čekijos archyvuose. Pavienių dokumentų, susijusių su Lietuvos kariuomene 1918-1940 m., taip pat galima rasti daugelyje kitų dokumentų rinkinių. Tik atlikus nuodugnias tematines paieškas, surinkus visą archyvinę informaciją, išsibarsčiusią po įvairius dokumentų rinkinius, bus galima susidaryti išsamų išlikusių Lietuvos kariuomenès istorijos dokumentų vaizdą. 